\title{
The Effect of Customer Relationship Management in Elderly Nursing Facilities on the Quality of Nursing Services in the Pandemic Era
} - Focusing on the Mediating Effect of Risk Management-

\section{팬데믹(pandemic) 시대 노인요양시설의 고객관계관리가 요양서비스 질에 미치는 영향 -리스크 관리 매개효과-}

Sun-Yeol Choi ${ }^{1}$, Jea-Ug Ko ${ }^{2}$

최선열 ${ }^{1}$, 고재욱 ${ }^{2}$

${ }^{1}$ Student, Department of Social Welfare, Catholic Kwandong University, Korea, uncle5326@hanmail.net

${ }^{2}$ Professor, Department of Social Welfare, Catholic Kwandong University, Korea, kojea62@cku.ac.kr

Corresponding author: Jea-Ug Ko

\begin{abstract}
This study sought to establish a trusting relationship in nursing care services as anxiety and stress arise in the inmates and their guardians, and workers of elderly nursing facilities due to the changes in the social and ecological system environment of the COVID-19 pandemic. The protracted corona pandemic creates emotional, psychological, and mental disorders due to corresponding restrictions on citizens' social activities, causing distrust in people's interpersonal interactions. Therefore, this study aimed to improve the quality of care services through risk management and customer relationship management, by regarding the inmates and their guardians in elderly nursing facilities as customers. The subjects of this study were professional caregivers working at elderly nursing facilities located in $\mathrm{G}$ province. In-depth interviews were carried out using a questionnaire and a final 300 answered copies were used in the final analysis. The research results found that customer relationship management directly influences risk management, and customer relationship management and risk management influence the quality of care services. It was confirmed that risk management plays a mediating role between customer relationship management and the quality of care services. These findings suggest that a trusting relationship can be built up through customer relationship management, thereby easing the anxiety and distrust about the quality of care services in a pandemic era. It further indicates that risk management promotes physical and emotional safety in inmates' facility life and influences the quality of care services, pointing the need to establish a systematic risk management system in the facility. In addition, customer relationship management and risk management are considered to be opportunities to gain a competitive edge in the competitive landscape caused by the marketization and fee-for-service of nursing care services.
\end{abstract}

Keywords:COVID-19 Pandemic, Elderly Nursing Facility, Caregiver, Customer Relationship Management, Risk Management, Quality of Care Service 
요약: 본 연구는 코로나19 팬데믹의 사회적 생태 체계 환경 변화에 노인요양시설의 입소자와 종사자 그리고 그 보호자의 불안과 스트레스로 인한 요양 서비스의 신뢰 관계 구축을 목적으 로 연구하였다. 장기화되고 있는 코로나 팬데믹은 시민들의 사회활동 제약으로 정서적, 심리 적, 정신적 장애를 생성하며 대인관계 상호작용 간에 불신을 야기하고 있다. 따라서 노인요양 시설에서의 입소자와 보호자를 고객으로 보고 고객 관계관리를 실행하고 더불어 리스크 관리 를 통해 요양서비스 질을 향상하고자 하는데 중점이 있다. 연구 대상은 $\mathrm{G}$ 도에 소재한 노인요 양시설에서 근무하는 요양보호사로 선정하였으며, 설문지는 설문조사를 통해 작성하였고 300 부를 최종 분석으로 활용하였다. 연구 결과에서 고객관계관리는 리스크 관리에 직접적인 영향 을 미치고, 고객관계관리와 리스크 관리는 요양서비스 질에 영향이 미치는 결과를 도출하였 다. 리스크 관리는 고객관계관리와 요양서비스 질 사이에서 매개 역할을 하는 것으로 확인되 었다. 이는 팬데믹 시대 요양서비스 질에 대한 불안, 불신을 고객관계관리를 통해 신뢰관계를 구축할 수 있다. 여기에 리스크 관리는 입소자의 시설 생활에서 신체적, 정서적 안정을 도모하 여 요양서비스 질 향상에 영향을 주게 된다. 따라서 시설은 체계적인 리스크 관리 시스템 구 축이 필요할 뿐만 아니라 고객관계관리와 리스크 관리는 요양 서비스의 시장화, 유료화로 인 한 경쟁 구도에서 경쟁우위를 점할 수 있는 기회가 될 것으로 사료된다.

핵심어: 코로나19 팬데믹, 노인요양시설, 요양보호사, 고객 관계관리, 리스크 관리, 요양서비스 질

\section{1. 서론}

\section{1 연구의 필요성}

코로나19로 인한‘사회적 거리 두기'등으로 지인 등 직접 만날 수 없기 때문에 인간관계가 나빠지고 고립감, 불안감, 상실감을 느끼며 호소하는 시민들이 늘고 있다. 무엇보다 새로운 사회현상인'사회적 거리 두기'는 인간에게 사회적 단절이 되고 있다. 이로 인해 정신적 장애를 비롯해 신체적 문제까지 영향을 미치고 있다. 인간은 사회적 동물이므로 인간관계를 중요시하고, 집단에 참여하려는 욕구와 자신의 감정을 타인과의 의사소통으로 위로와 위안을 받으며 치유와 행복감을 느끼게 된다.

코로나19의‘사회적 거리 두기'등으로 인간이 물리적인 통제를 받게 되면서 기본적인 욕구인 사람들과의 접촉이 제약을 받고 있는 가운데 코로나 19 가 장기화되면 외로움, 실망감, 절망감이 심화될 것으로 판단된다. 이러한 코로나19 팬데믹 시대의 갑작스럽고 예측하지 못한 변화는 사회는 물론 개인과 가족에게 스트레스의 근원이 되어 정신건강을 위협하는 것으로 밝혀졌다[1-3]. 또한 세계보건기구(WHO, 2020)는 코로나19를 '전례 없는 정신보건 위기' 라고 경고했으며, 코로나19가 지속되면서 사람들은 스트레스, 불안, 우울 등과 같은 정신적 문제를 격으면서 'mentaldemic' (멘탈과 팬데믹의 합성어)이라는 신조어까지 양산되었다[4-7]. 특히 시설은 입소자 대부분이 고령과 기저질환 등의 병력이 있어 코로나19 감염의 취약계층으로 분류되었다. 이에 노인 관련 기관과 요양 시설들은 보건복지부의 철저한 방역지침 준수를 권고받게 되면서 가족, 지인과의 면회가 제한되었다. 면회의 제한은 사회적으로 노인 인권으로 부각되고 관련 정부기관, 시설에 민원 제기와 함께 입소자들은 팬데믹의 사회적 현상을 알지 못한 상황에서 자녀들에게 소외감, 고립감을 호소하고 있다. 게다가 입소자들은 불안, 우울, 초조, 의욕과 식욕의 
저하와 같은 증상이 나타나고 있다. 그리고 2021년 10월 4주 차 현재 거리 두기는 수도권 4단계, 비수도권 3단계를 적용하고 있다. 정부는 다음 달 11 월 위드 코로나 정책 전환을 선언할 예정으로 팬데믹 상황이 장기화될 수 있음을 시사하고 있다. 장기화되고 있는 팬데믹 사회현상에서는 지방자치단체, 관련 정부기관, 공공기관과의 신뢰 관계에 따라 개인적인 위험 인식과 반응에 차이가 있을 수 있다. 특히 개인의 정부, 의료체계, 미디어, 대인에 대한 불신이 극심할수록 전염병에 대한 불확실성의 수준이 높아지게 되어 신종 전염병에 대한 공포감이 더욱 증폭될 수 있다[8][9].

이와 같은 코로나19 팬데믹의 영향으로 사회적, 대중적으로 노인요양시설의 각종 리스크에 대한 이목이 집중되고 있으며, 특히 입소자와 관련한 요양서비스 질에 더 많은 관심을 나타내고 있다.

본 연구와 관련된 선행연구에서 고객관계관리가 고객지향성과 서비스 질에 직접적인 영향을 미치고, 리스크 관리가 고객지향성과 서비스 질에 중요한 매개 기능을 한다는 연구[10][11] 결과를 보면, 노인요양시설의 고객관계관리와 리스크 관리는 요양서비스 질에 영향요인임을 유추할 수 있고, 코로나19 감염병의 리스크 관리 또한 요양서비스 질에 긍정적인 영향요소로 예측할 수 있다.

노인요양시설 종사자의 고객관계관리 능력의 제고는 고객의 주관적인 판단인 서비스 질에 대한 신뢰가 형성 될 것이고, 체계화된 시스템적인 리스크 관리는 요양서비스 질에 긍정적인 영향을 미치게 될 것이다. 또한 코로나19 팬데믹의 사회적 환경에서 노인요양시설의 요양서비스 질에 대한 사회적 신뢰가 형성됨을 기대한다. 그리고 현장에서 서비스 질의 향상에 실질적인 사례와 방법을 제시하는 데 의의를 둘 수 있다.

본 연구는 팬데믹의 사회적 현상을 감안하여 입소자와 그 보호자 및 가족을 고객으로 보고 고객관계관리를 통해 요양서비스 질에 대한 신뢰관계를 구축하고, 또한 리스크 관리로 입소자가 안전하고 안심하게 서비스를 이용하면서 노후를 누릴 수 있도록 하는데 목적이 있다.

\section{2 연구 문제}

코로나19로 인해 노인요양시설이 외부와의 교류가 제한되면서 요양서비스 질에 관한 보호자의 모니터링에 사각지대가 발생하고 있다. 이러한 사회적 분위기에 시설은 요양서비스 질을 위한 신뢰 형성의 전략이 필요하다. 이 전략의 요소 중에서 입소자의 안전과 관련된 리스크 관리와 입소자와 그 보호자와의 신뢰 관계 형성을 위한 고객관계관리는 코로나19 팬데믹 시대에서 필수 요소라고 할 수 있다.

연구 문제는 다음과 같다.

연구 문제 1. 코로나19로 인한 노인요양시설의 고객관계관리는 리스크 관리에 영향을 확인하고

연구 문제 2. 코로나19로 인한 노인요양시설의 고객관계관리는 리스크 관리에 어떠한 관계를 하는지를 검증한다.

연구 문제 3. 코로나19로 인한 고객관계관리는 요양서비스 질 사이에서 리스크 관리 영향 관계를 확인하고자 한다. 


\section{2. 연구 방법}

\section{1 연구 모형}

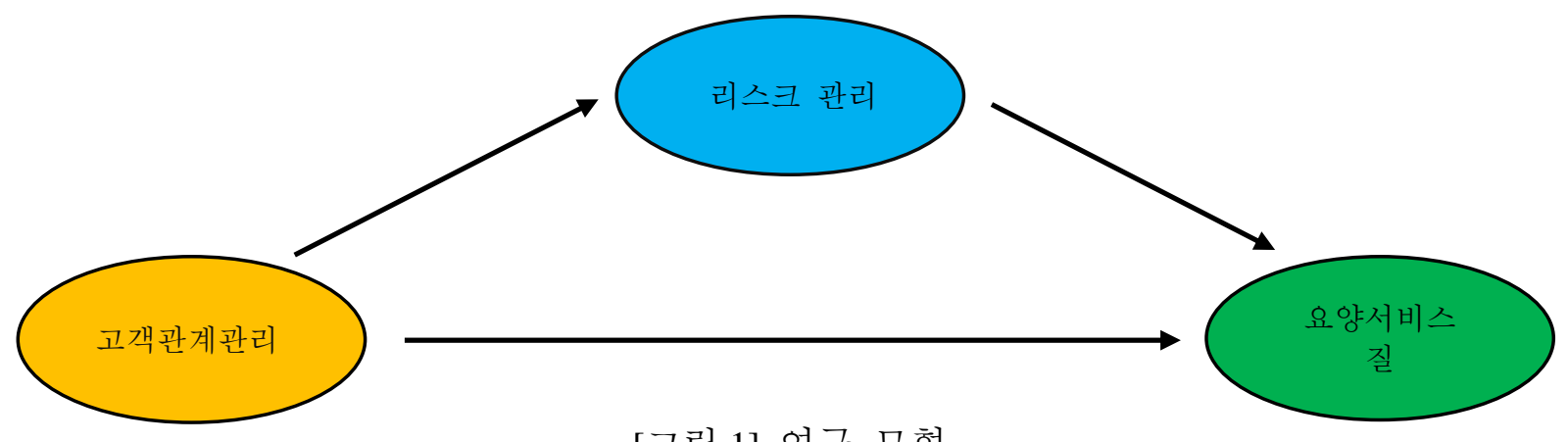

[그림 1] 연구 모형

[Fig. 1] Research Models

\section{2 연구 가설}

가설 $1:$ 고객관계관리는 리스크 관리에 정 $(+)$ 의 영향을 미칠 것이다.

가설 2: 리스크 관리는 요양서비스 질에 정 $(+)$ 의 영향을 미칠 것이다.

가설 3 : 고객관계관리는 요양서비스 질에 정 $(+)$ 의 영향을 미칠 것이다.

가설 4 : 고객관계관리가 요양서비스 질에 미치는 영향에 대해서 리스크 관리는 매개효과를 보일 것이다.

\section{3 연구 대상 및 자료 수집}

본 연구의 조사대상은 $\mathrm{G}$ 도에 소재하고 있는 노인요양시설에서 종사하는 요양보호사를 대상으로 하였으며, 구조화된 설문지로 설문조사 방법을 사용하였다. 설문지는 2021년 5월 11 일부터 5월 31 일까지 진행과 회수를 하였다. 노인요양시설의 노쇠한 이용자들은 인지 기능과 감각기능에 손상이 있어 안전에 대해 취약하고[12], 요양보호사는 요양 시설 노동력의 주요한 부분으로 이용자 안전을 향상시키는데 특별한 위치에 있다[13]. 따라서 요양 서비스는 요양보호사가 중추적인 역할을 하고 있으며, 이들의 위험 인식이 매우 중요할 뿐만 아니라 고객관계관리에도 핵심 종사자로 판단되어 연구 대상을 노인요양시설 요양보호사로 하였다. 첫 단계는 전화로 시설장 및 관리자에게 연구 목적과 취지, 설문 방법을 설명한 후 설문조사에 대한 동의를 구했다. 본 연구자가 각 시설을 직접 내원해서 윤리적 문제를 감안하여 요양보호사에게 연구목적과 취지를 서면의 내용을 바탕으로 구두로 충분히 설명하고, 연구에 참여하지 않아도 어떤 불이익도 없으며, 익명성 또한 보장됨을 설명하였다. 설문의 응답 내용은 연구목적과 달리 사용하지 않음을 충분히 이해시키고, 연구 참여자의 동의 후 설문조사를 하였다. $\mathrm{G}$ 도 소재 노인요양시설 19 개소와 노인 요양 공동생활가정 3 개소 총 22 개소의 요양보호사 327 명을 대상으로 하였다. 미회수 및 내용이 부적절한 27 부를 제외한 300 부를 가지고 신뢰도, 타당성을 분석하였고, 연구의 최종 분석에 활용하였다. 


\section{4 측정도구}

\subsection{1 고객관계관리}

본 연구는 Wang과 Feng[14] 등의 위계적 구성 모델과 Payne과 Frow[15]의 위계적 선행 모델을 통해 상위개념과 하위 차원 사이의 관계를 활용하여 이득규[16]가 개발한 고객관계관리 활동 척도를 설문에 사용하였다. 고객관계관리 활동 척도 54 개 문항에서 고객 신뢰수준과 연관된 고객지향적 활동, 고객 상호작용, 고객관계회복역량의 3 가지 영역을 재구성하여 총 17 개 문항을 활용하였다. 각 문항은 “전혀 아니다 매우 그렇다” 로 구성하였으며, 측정 점수가 높을수록 요양서비스 질은 높음을 의미한다. 각 문항은 리커트 5점 척도의 방식으로 응답하게 하였다. 사용한 척도는 "1은 전혀 아니다, 2는 아니다, 3은 보통이다, 4는 그렇다, 5는 매우 그렇다” 로 구성하였으며, 본 연구에서 신뢰도는 0.907-0.936으로 나타났다.

\subsection{2 리스크 관리}

본 연구에서는 연구자가 현장 경험을 바탕으로 서비스 제공 과정에서 위험요소의 빈도와 확률을 근거로 하고, 노인요양시설 종사자의 심층 인터뷰로 위험요소를 도출하였다. 또한 각 시설장 및 관리자와 현장 전문가의 조언과 검증을 받았다. 이 척도는 45 문항으로 요양보호사들의 개인의 위험 인식 수준을 바탕으로 주관적 평가로 측정하였다. 이 측정은 노인요양시설에 종사하는 요양보호사들이 직접 또는 간접경험을 평가할 수 있도록 구성하였다. 리스크 관리의 각 문항은 위험요소에 대한 개인적 위험 인식 수준에 따라 “전혀 아니다 매우 그렇다" 로 구성하였으며, 측정 점수는 리스크 관리에 대한 위험 인식 수준이 높을수록 요양서비스 질은 높아짐을 의미한다. 각 문항은 리커트 5점 척도의 방식으로 응답하게 하였다. 사용한 척도는 " 1 은 전혀 아니다, 2는 아니다, 3은 보통이다, 4는 그렇다, 5는 매우 그렇다” 로 구성하였으며, 신뢰도가 0.8810.966 으로서 신뢰도가 있는 것으로 나타났다.

\subsection{3 요양서비스 질}

본 연구의 요양서비스 질은 Parasuraman et $\mathrm{al}[17]$ 에 의해 개발된 서비스 질 척도를 한국어로 번안되어 이영희[18], 진완길[19]이 사용한 척도를 활용하였다. 이 척도는 20 문항으로 구성되어 있으며, 설문 응답자의 개인적, 주관적 평가로 측정을 하였다. 요양서비스 질의 각 문항은 “전혀 아니다 매우 그렇다” 로 구성했으며 측정한 점수가 높을수록 요양서비스 질이 높음을 의미한다. 각 문항은 리커트 5점 척도의 방식으로 응답하게 하였다. 사용한 척도는 " 1 은 전혀 아니다, 2 는 아니다, 3 은 보통이다, 4 는 그렇다, 5는 매우 그렇다” 로 구성하였으며, 이 척도의 신뢰도는 Cronbach's $\alpha=856$ 으로 보고되었다. 본 연구에서는 신뢰도가 0.883-0.921로서 신뢰도가 있는 것으로 나타났다.

\section{5 자료처리 방법}

본 연구에서는 수집된 설문지를 코딩한 후, SPSS ver23.0과 AMOS 23.0 프로그램을 사용하여 분석을 실시하였으며, 통계적 검증을 위하여 유의수준은 $\mathrm{p}<0.05$ 로 설정하여 연구를 진행하였다.

첫째, 표본의 인구통계적 요인을 분석하기 위하여 빈도 분석을 실시하였다. 
둘째, 측정도구의 타당성을 분석하기 위하여 탐색적 요인분석과 확인적 요인분석을 실시하고, 신뢰도 검증을 실시하였다.

셋째, 측정변수 간의 상관관계를 분석하기 위해 상관분석, 측정변수의 평균, 표준편차, 왜도, 첨도를 위해 기술 통계분석을 실시하였다.

넷째, 측정변수 간의 직접 효과를 분석하기 위하여 구조방정식 모형을 사용하여 분석하였다.

다섯째, 리스크 관리의 매개효과를 분석하기 위하여 Bootstrapping 분석을 실시하였다.

\section{3.연구 결과}

\section{1 표본의 인구통계적 요인}

표본의 인구통계적 요인에 대해 분석한 결과, 성별에서는 여자가 $91.7 \%$, 남자가 $8.3 \%$ 로 나타났고, 연령에서는 50 대가 $47.3 \%$ 로 가장 많았으며, 60 대 이상, 40 대, 30 대 이하의 순으로 나타났다. 학력에서는 고졸이 $59.7 \%$ 로 가장 많았으며, 전문대 졸, 대졸, 중졸 이하, 대학원 이상의 순으로 나타났고, 종교 유무에서는 무가 $53.7 \%$, 유가 $46.3 \%$ 로 나타났고, 결혼 상태에서는 기혼이 $91.7 \%$, 미혼이 $8.3 \%$ 로 나타났다. 요양보호사 외 자격증에서는 없음이 $47.0 \%$ 로 가장 많았으며, 공인, 기타, 민간의 순으로 나타났으며, 총 근무연수에서는 1-3년이 37.3\%로 가장 많았으며, 6-10년, 4-5년, 1-년 미만, 11년 이상의 순으로 나타났다. 현 근무연수에서는 1-3년이 48.0\%로 가장 많았으며, 1년 미만, 4-5년, 610 년의 순으로 나타났으며, 시설 입소 총원에서는 29 인 이하가 $48.7 \%$ 로 가장 많았으며, 49인 이하, 50-99인 이하, 9인 이하의 순으로 나타났다.

\section{2 측정변수에 대한 타당성 및 신뢰도 분석}

\subsection{1 측정변수에 대한 탐색적 요인분석 및 신뢰도 분석}

측정변수에 대한 탐색적 요인분석을 실시하기 위해 요인분석의 방법으로는 주성분 분석을 실시하였으며, 요인의 회전은 직교 회전의 하나인 베리맥스 로테이션을 사용하였다. 그리고 요인 수의 결정은 아이겐값을 기준으로 1.0 이상으로 설정하였고, 요인 적재치가 0.4 이하인 문항은 분석에서 제외하였다. 측정변수의 신뢰도를 분석하기 위하여 내적 일관성을 분석하는 Cronbach's Alpha 값을 사용하였다.

고객관계관리에 대해서 탐색적 요인분석을 실시한 결과, 3 개의 요인으로 추출되었으며, 추출된 요인의 아이겐값은 3.878-5.081로 나타났으며, $\mathrm{KMO}=0.949$ 로서 요인분석이 통계적으로 유의미하게 실시된 것으로 나타났다. 그리고 총 누적 변량이 76.011로 나타나고 있어 요인분석의 설명력이 $76.011 \%$ 인 것으로 나타났으며, 신뢰도가 $0.907-$ 0.936으로서 신뢰도가 있는 것으로 나타났다. 이후의 분석에서는 각 요인의 산술평균을 산출해 분석에 사용하였다.

요양서비스 질에 대해서 탐색적 요인분석을 실시한 결과, 5 개의 요인으로 추출되었으며, 추출된 요인의 아이겐값은 2.318-3.654로 나타났으며, $\mathrm{KMO}=0.954$ 로서 요인분석이 통계적으로 유의미하게 실시된 것으로 나타났다. 그리고 총 누적 변량이 81.1039로 나타나고 있어 요인분석의 설명력이 $81.139 \%$ 인 것으로 나타났으며, 신뢰도가 $0.883-$ 0.921로서 신뢰도가 있는 것으로 나타났다. 이후의 분석에서는 각 요인의 산술평균을 산출해 분석에 사용하였다. 
리스크 관리에 대해서 탐색적 요인분석을 실시한 결과, 5 개의 요인으로 추출되었으며, 추출된 요인의 아이겐값은 2.762-6.050으로 나타났으며, $\mathrm{KMO}=0.943$ 으로서 요인분석이 통계적으로 유의미하게 실시된 것으로 나타났다. 그리고 총 누적 변량이 74.483 으로 나타나고 있어 요인분석의 설명력이 $74.483 \%$ 인 것으로 나타났으며, 신뢰도가 $0.881-$ 0.966으로서 신뢰도가 있는 것으로 나타났다. 이후의 분석에서는 각 요인의 산술평균을 산출해 분석에 사용하였다.

\subsection{2 측정변수에 대한 확인적 요인분석}

[표 1] 확인적 요인분석에 대한 적합도 분석

[Table 1] Fit Analysis of Confirmatory Factor Analysis

\begin{tabular}{ccccccc}
\hline 구 분 & $\mathrm{CMIN} / \mathrm{DF}$ & $\mathrm{RMR}$ & $\mathrm{GFI}$ & $\mathrm{NFI}$ & $\mathrm{CFI}$ & $\mathrm{RMSEA}$ \\
\hline 모형 & 2.458 & .026 & .930 & .950 & .969 & .070 \\
\hline 기준 & $<3.0$ & $<.05$ & $>.9$ & $>.9$ & $>.9$ & $<.08$ \\
\hline
\end{tabular}

측정변수에 대한 확인적 요인분석에 대한 적합도를 분석한 결과, $\mathrm{CMIN} / \mathrm{DF}=2.458$, $\mathrm{RMR}=0.026, \mathrm{GFI}=0.930, \mathrm{NFI}=0.950, \mathrm{CFI}=0.969, \mathrm{RMSEA}=0.070$ 으로서 기준치를 모두 만족하는 것으로 나타났다. 즉 확인적 요인분석에 대한 적합도는 높다고 볼 수 있다.

[표 2] 확인적 요인분석

[Table 2] Confirmatory Factor Analysis

\begin{tabular}{|c|c|c|c|c|c|c|c|}
\hline \multicolumn{3}{|c|}{ 경로 } & \multirow{2}{*}{$\begin{array}{c}\text { 비표준화 } \\
.924\end{array}$} & \multirow{2}{*}{$\begin{array}{c}\text { 표준화 } \\
.851\end{array}$} & \multirow{2}{*}{$\begin{array}{l}\text { SE } \\
.047\end{array}$} & \multirow{2}{*}{$\begin{array}{c}\mathrm{t} \\
19.509^{* * *}\end{array}$} & \multirow{2}{*}{$\begin{array}{c}\mathrm{p} \\
.000\end{array}$} \\
\hline 고객지향 & $<--$ & 고객관계관리 & & & & & \\
\hline 고객상호 & $<---$ & 고객관계관리 & 1.000 & .924 & & & \\
\hline 관계회복 & $<---$ & 고객관계관리 & .873 & .808 & .048 & $18.006^{* * *}$ & .000 \\
\hline 돌봄지원 & $<--$ & 리스크관리 & .715 & .775 & .043 & $16.768^{* * *}$ & .000 \\
\hline 환자이송 & $<---$ & 리스크관리 & .660 & .714 & .045 & $14.712 * * *$ & .000 \\
\hline 사고예방 & $<---$ & 리스크관리 & .976 & .863 & .048 & $20.200 * * *$ & .000 \\
\hline 감염관리 & $<---$ & 리스크관리 & 1.000 & .898 & & & \\
\hline 정서지원 & $<--$ & 리스크관리 & .854 & .720 & .057 & $14.901 * * *$ & .000 \\
\hline 신뢰성 & <--- & 요양서비스 질 & .863 & .857 & .039 & $21.971 * * *$ & .000 \\
\hline 대응성 & $<---$ & 요양서비스 질 & .993 & .916 & .039 & $25.704 * * *$ & .000 \\
\hline 보증성 & $<--$ & 요양서비스 질 & 1.000 & .918 & & & \\
\hline 공감성 & $<---$ & 요양서비스 질 & .897 & .747 & .054 & $16.673^{* * *}$ & .000 \\
\hline 유형성 & $<---$ & 요양서비스 질 & .776 & .765 & .045 & $17.403 * * *$ & .000 \\
\hline
\end{tabular}

$* * * \mathrm{p}<.001$

측정변수에 대한 확인적 요인분석 결과, 고객관계관리, 리스크 관리, 요양서비스 질의 하위 변수들이 모두 통계적으로 유의미하게 해당 변수를 설명하는 것으로 나타났다. 


\section{3 측정변수에 대한 상관분석}

측정변수에 대한 상관관계를 분석한 결과, 고객관계관리, 리스크 관리, 요양서비스 질의 하위 변수 간에는 대부분 정 $(+)$ 의 상관관계를 보이는 것으로 나타났다. 이는 본 연구자가 설정한 연구의 방향성과 동일한 것으로 판별 타당성이 입증되었다고 볼 수 있다. 그리고 고객관계관리에서는 고객 상호가 4.33으로 가장 높게 나타났고, 요양서비스 질에서는 보증성이 4.27로 가장 높았으며, 리스크 관리에서는 환자 이송이 3.30 으로 가장 높게 나타났다.

\section{[표 3] 측정변수 간 상관분석}

[Table 3] Correlation Analysis between Measurement Variables

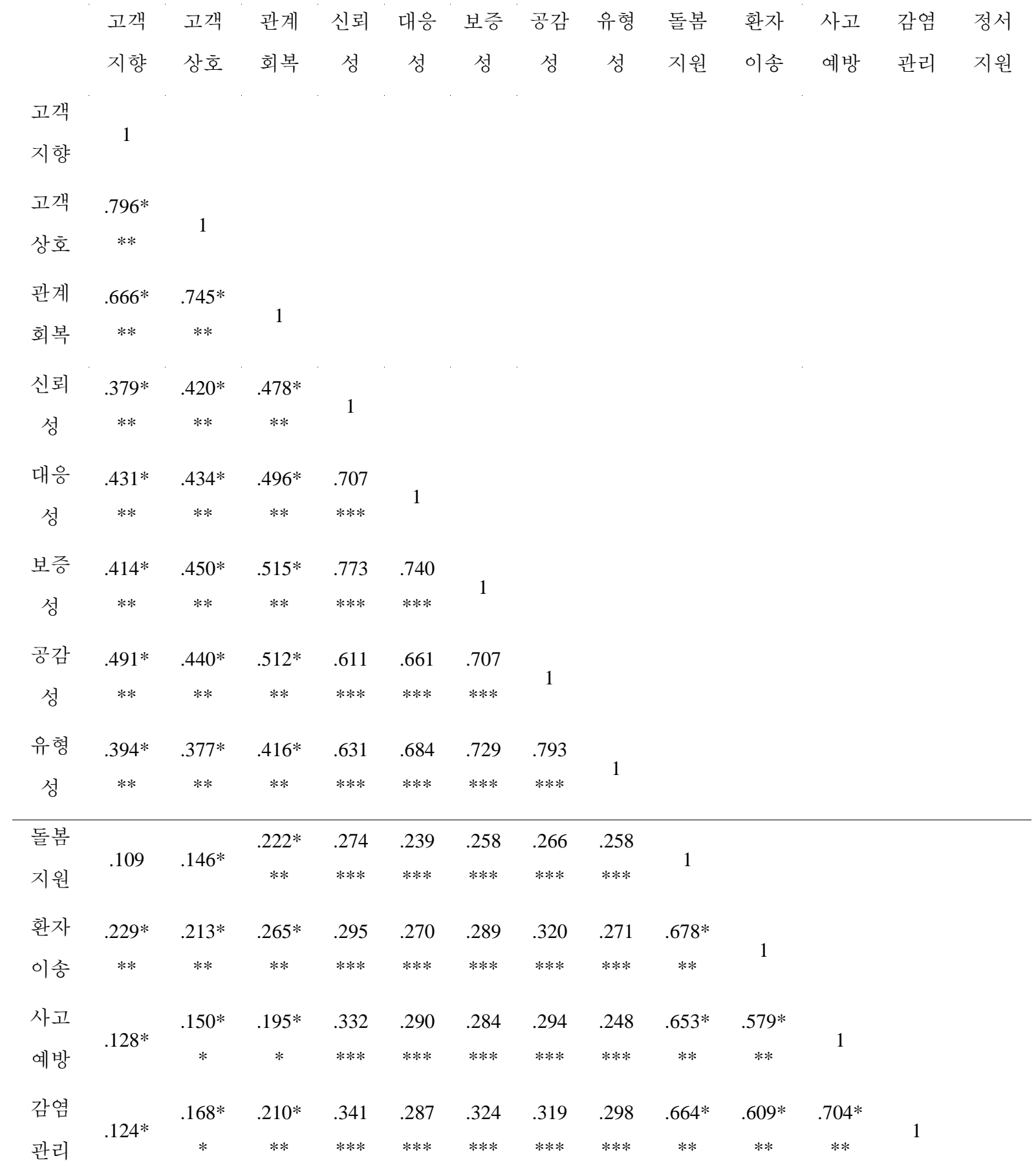




\begin{tabular}{cccccccccccccc} 
정서 & $.184 *$ & $.242 *$ & $.256 *$ & .284 & .233 & .243 & .235 & .191 & $.576 *$ & $.526 *$ & $.592 *$ & $.657 *$ \\
지원 & $*$ & $* *$ & $* *$ & $* * *$ & $* * *$ & $* * *$ & $* * *$ & $* *$ & $* *$ & $* *$ & $* *$ & $* *$ & 1 \\
\hline $\mathrm{M}$ & 4.26 & 4.33 & 4.13 & 4.21 & 4.23 & 4.27 & 4.00 & 4.10 & 2.89 & 3.30 & 2.70 & 2.94 & 3.27 \\
\hline $\mathrm{SD}$ & .59 & .59 & .58 & .55 & .60 & .60 & .66 & .56 & .87 & .88 & 1.07 & 1.05 & 1.12 \\
\hline
\end{tabular}

$* \mathrm{p}<.05, * * \mathrm{p}<.01, * * * \mathrm{p}<.001$

\section{4 연구 모형의 검증}

\subsection{1 직접 효과 분석}

[표 4] 연구 모형에 대한 적합도 분석

[Table 4] Analysis of Fit for Research Model

\begin{tabular}{ccccccc}
\hline 구 분 & CMIN/DF & RMR & GFI & NFI & CFI & RMSEA \\
\hline 모형 & 1.954 & .025 & .945 & .961 & .980 & .056 \\
\hline 기준 & $<3.0$ & $<.05$ & $>.9$ & $>.9$ & $>.9$ & $<.08$ \\
\hline
\end{tabular}

본 연구자가 연구목적 및 이론적 배경을 바탕으로 설정한 연구 모형에 대한 적합도를 분석한 결과, $\mathrm{CMIN} / \mathrm{DF}=1.954, \quad \mathrm{RMR}=0.025, \quad \mathrm{GFI}=0.945, \quad \mathrm{NFI}=0.961, \quad \mathrm{CFI}=0.980$, $\mathrm{RMSEA}=0.056$ 으로서 기준치를 모두 만족하는 것으로 나타났다. 즉 본 연구자가 설정한 연구 모형의 적합도가 높은 수준임을 알 수 있다.

[표 5] 연구 모형에 대한 직접 효과 분석

[Table 5] Analysis of Direct Effects on the Research Model

\begin{tabular}{cccccccc}
\hline & 경로 & & 비표준화 & 표준화 & $\mathrm{SE}$ & $\mathrm{t}$ & $\mathrm{p}$ \\
\hline 리스크관리 & $<---$ & 고객관계관리 & .409 & .230 & .111 & $3.683 * * *$ & .000 \\
\hline 요양서비스 질 & $<---$ & 리스크관리 & .156 & .274 & .030 & $5.151^{* * *}$ & .000 \\
\hline 요양서비스 질 & $<---$ & 고객관계관리 & .509 & .502 & .056 & $9.095 * * *$ & .000 \\
\hline
\end{tabular}

$* * * \mathrm{p}<.001$

연구 모형에 대한 직접 효과를 분석한 결과, 고객관계관리는 리스크 관리에 통계적으로 정 $(+)$ 의 영향을 미치는 것으로 나타났다 $(\mathrm{t}=3.683, \mathrm{p}<0.001)$. 이는 고객관계관리가 향상될수록 리스크 관리 또한 향상되는 것이라고 볼 수 있다. 리스크 관리는 요양서비스 질에 통계적으로 정 $(+)$ 의 영향을 미치는 것으로 나타났다 $(\mathrm{t}=5.151$, $\mathrm{p}<0.001)$. 이는 리스크 관리가 향상될수록 요양서비스 질 또한 향상되는 것이라고 볼 수 있다. 고객관계관리가 요양서비스 질에 통계적으로 정 $(+)$ 의 영향을 미치는 것으로 나타났다 $(\mathrm{t}=9.095, \mathrm{p}<0.001)$. 이는 고객관계관리가 향상될수록 요양서비스 질 또한 향상되는 것이라고 볼 수 있다. 즉, 고객관계관리는 리스크 관리와 요양서비스 질에 영향을 미치며, 리스크 관리도 요양서비스 질에 영향을 미친다는 것을 알 수 있다. 


\subsection{2 간접효과분석}

고객관계관리가 요양서비스 질에 미치는 영향에 대한 리스크 관리의 매개효과를 분석하기 위하여 Bootstrapping 분석을 실시하였다. Bootstrapping 분석에서 직접효과와 간접효과가 있을 경우 부분매개효과라고 하며, 간접효과만 있을 경우는 완전매개효과가 있다고 판단한다.

[표 6] 리스크 관리의 매개효과 분석

[Table 6] Analysis of Mediating Effects of Risk Management

\begin{tabular}{rrrc}
\hline & 총효과 & 직접효과 & 간접효과 \\
\hline 매개효과 & $.565^{* *}$ & $.502 * *$ & $.063 * *$ \\
\hline$* * \mathrm{p}<.01$ & & &
\end{tabular}

고객관계관리가 요양서비스 질에 미치는 영향에 대한 리스크 관리의 매개효과를 분석한 결과, 직접효과 $(G=0.502, \mathrm{p}<0.01)$ 와 간접효과 $(G=0.063, \mathrm{p}<0.01)$ 가 모두 통계적으로 있는 것으로 나타났다. 이는 고객관계관리가 요양서비스 질에 직접적으로도 영향을 미치지만 리스크 관리를 통해 간접적으로도 영향을 미친다는 것을 확인할 수 있었다.

\section{4. 결론}

코로나19 팬데믹의 사회적 현상은 국지적 현상이 아닌 국제적으로 다양한 형태로 영향을 미치고 있는 가운데 개인과 조직이 변화되거나 스스로 변화하고 있다. 코로나19는 인류의 삶을 변화시키는데, 특히 산업기반, 의식, 교육, 국제관계, 사상, 사회질서 등 미시적인 장소에서 거시적인 공간까지 영향을 주고 있다. 이러한 사회적 변화는 사람을 기피하는 현상과 자신의 생각에 빠진 독선적 인간을 만들고 결국 “서로를 신뢰하지 않는 사회” 가 될 것이다. '사회적 거리 두기' 로 인해 시설 방문이 제한되면서 면회가 자유롭지 못하게 되었다. 게다가 코로나 19 와 관련된 언론 보도는 불안감을 조성하면서 노인요양시설에 감염의 우려가 집중되고, 특히 코로나19로 증폭된 불안은 시설의 요양서비스 질에 관심이 주목되고 있다. 그럼에도 불구하고 코로나19 감염병을 포함한 리스크 관리, 팬데믹으로 인한 서비스 이용자들의 불안, 불신을 극복하는 차원의 고객관계관리와 요양서비스 질과의 상호 연관성을 탐색한 연구는 미흡한 상태이다. 이에 본 연구는 입소자와 그 보호자를 고객으로 보고 고객관계관리가 리스크 관리와 요양서비스 질에 미치는 영향과 리스크 관리가 요양서비스 질에 미치는 영향을 알아보았다. 그리고 리스크 관리의 고객관계관리와 요양서비스 질 간에 매개효과를 검증하였다.

내용을 살펴보면 다음과 같다.

먼저, 노인요양시설의 고객관계관리는 리스크 관리에 직접적인 영향을 미치는 것으로 검증되었다. 이는 고객관계관리를 잘할수록 리스크 관리의 인식 수준이 높아짐을 시사한다. 이 결과는 노인요양시설에서 고객관계관리가 사고에 대한 예방적 차원에서 중요함을 확인한 결과이며, 사고예방을 위해서는 고객관계관리를 잘해야 함을 의미한다. 시설에서는 매우 다양하고 복잡한 이유로 리스크가 존재한다. 입소자는 대부분 신체적, 정신적 장애를 가지고 있으며, 입소자 단독이든 종사자의 실수 또는 방심으로 사고가 
발생하게 된다. 경미한 사고도 후유증으로 사망과 같은 큰 사고로 이어지기도 한다. 그러나 이와 같은 상황을 완벽하게 차단하는 것은 한계가 있으므로 시설 차원에서 고객관계관리 통하여 사전에 리스크를 차단하도록 노력하여 사고예방에 주목할 필요가 있다. 둘째, 노인요양시설의 고객관계관리는 요양서비스 질에 영향을 미치는 것으로 나타났다. 이는 입소자, 그 보호자 등 고객관계관리를 잘할수록 요양서비스 질은 높아짐을 의미한다. 이러한 결과는 팬데믹 사회적 분위기에서 고객관계관리의 중요성을 시사한다. 서비스 질은 고객의 과거 경험, 선입견 등 다양한 인지 경로를 통해 매우 주관적으로 판단되는 것이기 때문에 고객관계관리를 잘할수록 긍정적으로 받아들이게 된다. 또한 장기요양 보험제도로 요양 서비스의 시장화, 유료화가 되어 시설은 동종업계에서 비교우위를 점하기 위해서는 고객관계관리를 철저히 할 필요가 있다. 셋째, 노인요양시설의 리스크 관리는 요양서비스 질에 영향을 미치는 것으로 나타났다. 이는 요양보호사의 리스크 관리가 향상될수록 요양서비스 질이 향상됨을 의미한다. 서비스 제공자의 리스크 민감성은 세심한 서비스를 제공하는 계기가 되고, 서비스 이용자는 수준 높은 서비스를 제공받는 범위가 넓어지는 기회가 된다. 시설은 서비스 제공의 핵심인력인 요양보호사를 대상으로 리스크 관리 인식 및 민감성 확보, 사고의 예방적 차원에서 리스크 관리 교육이 진행되어야 한다. 이와 같은 리스크 관리를 위한 체계적인 활동은 입소자와 그 보호자가 인식하는 요양서비스 질이 높게 평가되고 지각될 것이다. 넷째, 고객관계관리와 노인요양시설 요양서비스 질 사이에 리스크 관리는 매개효과가 있는 것으로 검증되었다. 이는 시설에서 입소자, 그 보호자 등 고객관계관리를 통하여 리스크 관리를 진행하였을 때 요양서비스 질은 높아짐을 의미한다. 기본적으로 시설은 리스크에 취약한 계층이 서비스 대상이므로 서비스 제공자의 고객관계관리와 리스크 관리에 대한 인식이 매우 중요하다. 장기요양보험으로 보편적 노인복지와 서비스의 시장화, 유료화로 이용자의 권위가 상승하였고, 아울러 코로나19 팬데믹의 시대에 요양 서비스에 대한 불안과 불신을 극복하는 차원과 영리조직과 같이 시장에서 생존하기 위한 전략적 요소로 고객관계관리와 리스크 관리는 핵심과제가 될 것으로 사료된다.

\section{References}

[1] https://www.joongang.co.kr/article/23747507\#home, April 5 (2020)

[2] W. A. Kerr, The COVID-19 pandemic and agriculture: Short- and long-run implications for international trade relations, Canadian Journal of Agricultural Economics, (2020), Vol.68, No.2, pp.225-229, DOI: https://doi.org/10.1111/cjag.12230

[3] H. A. Swartz, The Role of Psychotherapy During the COVID-19 Pandemic, The American Journal of Psychotherapy, (2020), Vol.73, No.2, pp.41-42, DOI: https://doi.org/10.1176/appi.psychotherapy.20200015

[4] G. Chen, Q. Wu, H. Jiang, H. Zhang, J. Peng, J. Hu, C. Xie, Fear of disease progression and psychological stress in cancer patients under the outbreak of COVID-19, Psycho-Oncology, (2020), Vol.29, No.9, pp.1395-1398, DOI: https://doi.org/10.1002/pon.5451

[5] L. W. Coyne, E. R. Gould, M. Grimaldi, K. G. Wilson, G. Baffuto, A. Biglan, First things first: Parent psychological flexibility and self-compassion during COVID-19, Behavior Analysis in Practice, (2021), Vol.14, No.4, pp.1092-1098, DOI: $10.1007 / \mathrm{s} 40617-020-00435-\mathrm{w}$

[6] R. L. T. Montano, K. M. L. Acebes, Covid stress predicts depression, anxiety and stress symptoms of Filipino respondents, International Journal of Research in Business and Social Science, (2020), Vol.9, No.4, pp.78-103, DOI: 10.20525/ijrbs.v9i4.773 
The Effect of Customer Relationship Management in Elderly Nursing Facilities on the Quality of Nursing Services in the Pandemic Era - Focusing on the Mediating effect of risk management-

[7] U. Rehman, M. G. Shahnawaz, N. H. Khan, K. D. Kharshiing, M. Khursheed, K. Gupta, D. Kashyap, R. Uniyal, Depression, anxiety and stress among Indians in times of Covid-19 lockdown, Community Mental Health Journal, (2020), pp.1-7, DOI: 10.1007/s10597-020-00664-x

[8] A. Schimmenti, J. Billieux, V. Starcevic, The four horsemen of fear: An integrated model of understanding fear experiences during the COVID-19 pandemic, Clinical Neuropsychiatry, (2020), Vol.17, No.2, pp.41-45, DOI: https://doi.org/10.36131/CN20200202

[9] J. M. Shultz, J. L. Cooper, F. Baingana, M. A. Oquendo, Z. Espinel, B. M. Althouse, L. H. Marcelin, S. Towers, M. Espinola, C. B. McCoy, L. Mazurik, M. L. Wainberg, Y. Neria, A. Rechkemmer, The Role of Fear-Related Behaviors in the 2013-2016 West Africa Ebola Virus Disease Outbreak, Current Psychiatry Reports, (2016), Vol.18, No.11, p.104, DOI: $10.1007 / \mathrm{s} 11920-016-0741-\mathrm{y}$

[10] J. M. Moon, Factors Affecting CRM System Success and Customer Management Effectiveness research on, Hankuk University Of Foreign Studies Graduate School, Doctoral thesis, pp.57-63, (2004)

[11] D. Zohar, Safety Climate in Industrial Organizations: Theoretical and Applied Implications, Journal of Applied Psychology, (1980), Vol.65, No.1, pp.96-102, DOI: 10.1037/0021-9010.65.1.96

[12] A. F. Bonner, N. G. Castle, A. Men, S. M. Handler, Certified nursing assistants' perceptions of nursing home patient safety culture: Is there a relationship to clinical outcomes?, Journal of the American Medical Directors Association, (2009), Vol.10, No.1, pp.11-20, DOI: 10.1016/j.jamda.2008.06.004

[13] M. L. Wagner, C. Elizabeth, C. R. Julie, Nurses' Perceptions of Safety Culture in Long-Term Care Settings, Journal of Nursing Scholarship, (2009), Vol.41, No.2, pp.184-192, DOI: 10.1111/j.1547-5069.2009.01270.x

[14] Y. Wang, H. Feng, CRM capability in service industries: Conceptualization and scale development, 2008 IEEE International Conference on Service Operations and Logistics, and Informatics, pp.83-88, (2008), October 12-15, Beijing, China, DOI: 10.1109/SOLI.2008.4686367

[15] A. Payne, P. Frow, A Strategic Framework for Customer Relationship Management, Journal of Marketing, (2005), Vol.69, No.4, pp.167-176, DOI:https://doi.org/10.1509/jmkg.2005.69.4.167

[16] D. K. Lee, The development of A Scale to measure Customer Relationship Management(CRM) in Customer Perspective, Soongsil University graduate school, Doctoral thesis, pp.46-52, (2012)

[17] A. P. Parasuraman, V. A. Zeithaml, L. L. Berry, SERVQUAL: A multiple- Item Scale for measuring consumer perceptions of service quality, Journal of Retailing, (1988), Vol.64, No.1, pp.12-40.

[18] Y. H. Lee, Effect of Organization Immersion of Life Rehabilitation Teacher in Living Faculties for the Disabled to Quality of Service, Daegu Haany University Graduate School, Doctoral thesis, p.44, (2011)

[19] W. G. Jin, The Impact of Formal Caregivers' Organizational Commitment on Service Quality in Nursing Homes: Mediating Role of Job satisfaction, Honam University Graduate School, Doctoral thesis, pp.47-48, (2012) 